\title{
Journal of Molecular and Genetic Medicine
}

\section{First Report of Northern Corn Leaf Blight Disease Caused by Exserohilum turcicum on Zea mays in Malaysia}

\section{Bashir KA ${ }^{1,2 *}$, Kamaruzaman $\mathbf{S}^{1}$ and Khairulmazmi $\mathbf{A}^{1}$}

${ }^{1}$ Department of Plant Protection, Universiti Putra Malaysia, 43400 Serdang, Selangor, Malaysia

${ }^{2}$ Department of Biological Sciences, Federal University Dutsin-ma, P.M.B 5001, Dutsin-ma, Katsina State, Nigeria

\begin{abstract}
In April 2015, Northern corn leaf blight (NCLB) symptoms were observed in corn plants (Zea mays L.) in cold highland areas at Titi Gantong, Lembah Bertam farms, Malaysia. The typical symptom of NCLB disease showed abundant lesions on the leaves of susceptible cultivars $(5-20 \mathrm{~cm}$ long), greyish to tan in colour and elliptical in shape. Exserohilum turcicum (Pass.) was isolated from diseased leaf and cultured on PDA media for further morphological investigation. The colonies of E. turcicum on PDA are dark grey in colour and grow faster. Conidial shapes were straight to slightly curved, the hilum protrudes as a truncate at the base of the conidia. Conidial colour was pale to olivaceous brown, while the conidial size ranged from 56 to $89 \mu \mathrm{m}$ in length, 9 to $13 \mu \mathrm{m}$ in width, and the number of septa ranged from 6-10. Conidia were 4-9 distosptate, with a thicker wall at the base of each conidium. Based on description reported by Sivanesan (1987) the isolate was identified as E. turcicum. To verify the morphological findings, PCR amplification was conducted using universal primers, TUBUF2 forward (5' CGGTAACAACTGGGCCAAGG-3') and TUBUR1 reverse (5'-CCTGGTACTGCTGGTACTCAG-3') and yielded a 1000 -bp product. Blast result showed that the sequence was having $97 \%$ similarity to published sequence of Setosphaeria turcica, teleomorph of E. turcicum (Accession No. XM 008032318). To our belief and knowledge, this is the first report of E. turcicum as the causative agent of NCLB disease of corn in Malaysia. There is need for future studies to focus on assessing management options for this disease to avoid corn yield losses in Malaysia.
\end{abstract}

Keywords: Exserohilum turcicum; Malaysia; Northern corn leaf blight disease; Zea mays

\section{Introduction}

In April 2015, Northern Corn Leaf Blight (NCLB) symptoms were observed in corn plants (Zea mays L.) in cold highland areas at Titi Gantong, Lembah Bertam farms, Malaysia. The typical symptom of NCLB disease showed abundant lesions on the leaves of susceptible cultivars (5-20 cm long), greyish to tan in colour and elliptical in shape, in the presence of moisture the lesions might be covered with abundant black conidia of the fungus [1].

\section{Method}

Exserohilum turcicum (Pass.) was isolated from diseased leaf and cultured on PDA media for further morphological investigation. A 3-4-day old growing culture was used for this study. The growing culture in petri-plates were aseptically opened under laminar flow, a clean microscope glass slides were gently placed over the surface of the colonies touching the edge and the plates were resealed, followed by incubation under continuous light to produce spores. A total of five fungal isolates were studied for morphological and cultural characteristics after the culture reached 7-10 days. The colour and texture of the colony were also observed. Number of septa, conidial length, colour and width of 30 spores per each isolate were measured using eye piece micrometer and compound light microscope.

\section{Results}

The colonies of E. turcicum on PDA are dark grey in colour and grow faster (Figure 1A). Conidiophores were olivaceous brown, cylindrical, paler toward the apex, usually $8-10 \mu \mathrm{m}$ thick, and septate. Conidial shapes were straight to slightly curved, the hilum protrudes as a truncate at the base of the conidia (Figure 1B). Conidial colour was pale to olivaceous brown, while the conidial size ranged from 56 to $89 \mu \mathrm{m}$ in length, 9 to $13 \mu \mathrm{m}$ in width, and the number of septa ranged from 6-10 (Table 1). Conidia were 4-9 distosptate, with a thicker wall at the base of each conidium. Based on description reported by Sivanesan (1987) the isolate was identified as E. turcicum. To verify the morphological findings, PCR amplification was conducted using universal primers, TUBUF2 forward (5'-CGGTAACAACTGGGCCAAGG-3') and TUBUR1 reverse (5'-CCTGGTACTGCTGGTACTCAG-3') and yielded a 1000-bp product, the gene targeted was rRNA. Blast result showed that the sequence was having $97 \%$ similarity to published sequence of Setosphaeria turcica, teleomorph of E. turcicum (Accession No. XM_008032318). The sequence of isolate ET003 was deposited

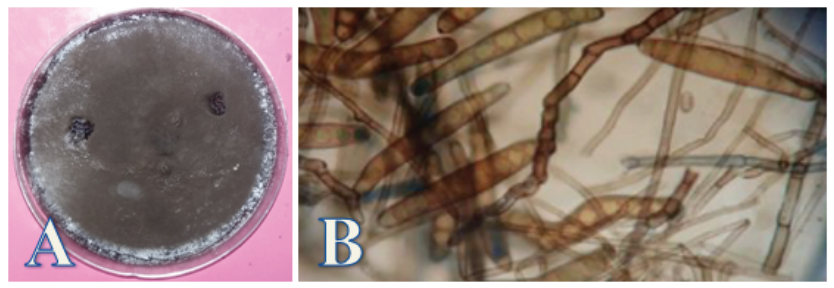

Figure 1: (A) Exserohilum turcicum culture showing dark grey colour when grown on PDA for a period of two weeks of incubation. (B) Straight or elongated spore with a protruding hilum viewed under compound light microscope (Magnification 40x).

*Corresponding author: Dr. Abdulaziz Kutawa Bashir, Department of Plant Protection Universiti Putra Malaysia, 43400 Serdang, Selangor, Malaysia and Department of Biological Sciences, Federal University Dutsin-ma, P.M.B 5001, Dutsin-ma, Katsina State, Nigeria, Tel: +234 813381 5243; E-mail: abashir@fudutsinma.edu.ng

Received November 14, 2018; Accepted December 18, 2018; Published December 22, 2018

Citation: Bashir KA, Kamaruzaman S, Khairulmazmi A (2018) First Report of Northern Corn Leaf Blight Disease Caused by Exserohilum turcicum on Zea mays in Malaysia. J Mol Genet Med 12: 387 doi:10.4172/1747-0862.1000387

Copyright: $\odot 2018$ Bashir KA, et al. This is an open-access article distributed under the terms of the Creative Commons Attribution License, which permits unrestricted use, distribution, and reproduction in any medium, provided the original author and source are credited 


\begin{tabular}{|c|c|c|c|c|c|}
\hline \multirow{2}{*}{$\begin{array}{l}\text { Isolate } \\
\text { Code }\end{array}$} & \multirow{2}{*}{ Location } & \multirow{2}{*}{$\begin{array}{l}\text { Type of } \\
\text { Pathogen } \\
\text { Growth }\end{array}$} & \multicolumn{2}{|c|}{ Conidia Measurement } & \multirow{2}{*}{$\begin{array}{l}\text { No of } \\
\text { septa }\end{array}$} \\
\hline & & & Length $(\mu \mathrm{m})$ & Width $(\mu \mathrm{m})$ & \\
\hline ET001 & $\begin{array}{l}\text { Titi Gantong } \\
\text { (Perak) }\end{array}$ & $\begin{array}{l}\text { Profused } \\
\text { growth }\end{array}$ & 65.38 & 13.74 & $6-8$ \\
\hline ET002 & $\begin{array}{l}\text { Titi Gantong } \\
\text { (Perak) }\end{array}$ & $\begin{array}{l}\text { Moderate } \\
\text { growth }\end{array}$ & 56.70 & 11.34 & $5-7$ \\
\hline ET003 & $\begin{array}{l}\text { Titi Gantong } \\
\text { (Perak) }\end{array}$ & $\begin{array}{l}\text { Profused } \\
\text { growth }\end{array}$ & 89.44 & 13.28 & $7-10$ \\
\hline ET004 & $\begin{array}{l}\text { Lembah Bertam } \\
\text { (Pahang) }\end{array}$ & $\begin{array}{l}\text { Moderate } \\
\text { growth }\end{array}$ & 78.42 & 12.63 & $6-9$ \\
\hline ET005 & $\begin{array}{l}\text { Lembah Bertam } \\
\text { (Pahang) }\end{array}$ & $\begin{array}{l}\text { Moderate } \\
\text { growth }\end{array}$ & 66.24 & 13.56 & 6-8 \\
\hline
\end{tabular}

Table 1: Morphological characteristics of Exserohilum turcicum conidia for all the five isolates.

in GenBank as KU670342. To confirm Koch's postulate, a 14-day old culture of isolate ET003 was used. About $15 \mathrm{ml}$ of sterilised distilled water was added into the plate containing a fully-grown mycelium, the mycelia were scrapped using sterilised glass rod, and the spore suspension was filtered into the beaker using muslin cloth. The filtered spore suspension was diluted with distilled water to get the best concentration $\left(10^{6}\right.$ spores $\left./ \mathrm{ml}\right)$. The spore suspension was sprayed on the leaf s surfaces continuously until runoff, a total of 10 corn seedlings (Thai super sweet) variety was used. Five seedlings were inoculated with spore suspension and the remaining five plants (control) were sprayed with sterilised distilled water. The plants were maintained in a glasshouse at $27-30^{\circ} \mathrm{C}$. Ten days after inoculation, $80 \%$ of the seedlings showed NCLB symptoms identical to those observed in the corn farms, while control seedlings did not show the symptoms. The pathogen was re-isolated from diseased leaves [2-4].

\section{Conclusion}

To our belief and knowledge, this is the first report of E. turcicum as the causative agent of NCLB disease of corn in Malaysia. At the end of this study, the variability of E. turcicum pathogen responsible for causing NCLB disease in Malaysia was studied, the pathogen was identified as E. turcicum using both morphological and molecular methods. There is need for future studies to focus on assessing management options for this disease to avoid corn yield losses in Malaysia.

\section{References}

1. Raymundo AD (1981) Effect of GeneHtNon the development of northern corn leaf blight epidemics. Plant Dis 65: 327.

2. Shankara K, Pradhan RS, Patole SP (2017) Yield loss assessment due to Turcicum leaf blight of maize caused by Exserohilum turcicum. Int $\mathrm{J}$ Curr Microbiol Appl Sci 6: 2888-2891.

3. Muiru WM, Mutitu EW, Kimenju JW (2009) Distribution of Turcicum leaf blight of maize in Kenya and cultural variability of its causal agent, Exserohilum turcicum. J Tropical Microbiol Biotechnol 4: 1-2.

4. Weems JD, Bradley CA (2017) Sensitivity of Exserohilum turcicum to demethylation inhibitor fungicides. Crop Protect 99: 85-92. 